\title{
PENGARUH MODEL PEMBELAJARAN AKTIF QUIZ TEAM TERHADAP KEMAMPUAN MENGIDENTIFIKASI INFORMASI TEKS EKSPLANASI OLEH SISWA KELAS VIII MTsN 2 MEDAN TAHUN PEMBELAJARAN 2019/2020
}

\author{
Mhd. Arpan ${ }^{1}$, Fitriani Lubis ${ }^{2}$ \\ E-mail : hasibuanarpan@gmail.com ${ }^{1}$, rianiavandi@gmail.com ${ }^{2}$ \\ Universitas Negeri Medan
}

\begin{abstract}
Abstrak
Penelitian ini bertujuan untuk meningkatkan Kemampuan Mengidentifikasi Informasi Teks Eksplanasi Oleh Siswa Kelas VIII MTsN 2 Medan melalui model pembelajaran aktif quiz team. Penggunaan model pembelajaran aktif quiz team diharapkan mampu mempermudah siswa dalam mengidentifikasi informasi dalam teks eksplanasi dan mampu meningkatkannya. Adapun tujuan penelitian ini adalah untuk mendeskripsikan keterampilan mengidentifikasi informasi sebelum dan sesudah menggunakan model pembelajaran aktif quiz team, mendeskripsikan pengaruh penggunaan model pembelajaran aktif quiz team terhadap kemampuan mengidentifikasi informasi siswa. Penelitian ini merupakan penelitian kuantitatif dengan bentuk eksperimen dan deskriptif dengan tipe tes awal-tipe tes akhir dengan kelompok tunggal (the one grup pre-test-post-test). Subyek penelitian ini adalah siswa kelas VIII MTsN 2 Medan dengan jumlah polulasi 444 siswa. Sampel dalam penelitian ini yaitu kelas VIII4, dengan jumlah 30 siswa). Nilai rata-rata pre-test siswa 64,16, dengan kategori cukup dan tidak memenuhi KKM yang ditenmtukan sekolah yaitu 70, sedangkan rata-rata nilai post-test siswa sebesar 84,15. Berdasarkan hasil analisis, diperoleh bahwa data berditribusi normal. Setelah dilakukan perhitungan uji normalitas $L_{\text {hitung }}<L_{\text {tabel }}$ pada tahap signifikan, hasil ui normalitas pre-test adalah (0,1328<0,161), hasil uji normalitas data post-test $(0,0877<0,161)$. Hasil uji homogenitaskemampuan mengidentifikaasi informasi teks eksplanasi adalah $F_{\text {hitung }}<F_{\text {tabel }}$ yakni 2,70<4,17 dan uji hipotesis $t_{\text {hitung }}>t_{\text {tabel }}$ yaitu 9,62 > 1,67, sehingga hipotesis nihil $\left(H_{0}\right)$ ditolak dan hipotesis alternatif $\left(H_{a}\right)$ diterima. Jadi dapat disimpulkan bahwa model pembelajaran aktif quiz team memiliki pengaruh terhadap kemampuan mengidentifikasi informasi teks eksplanasi siswa kelas VIII MTsN 2 Medan tahun pembelajaran 2019/2020.
\end{abstract}

Kata Kunci :teks eksplanasi, model quiz team.

\section{Pendahuluan}

Pendidikan merupakan salah satu peran yang sangat penting bagi sumber daya manusia dan bagi semua orang dan tidak dapat dipisahkan dalam kehidupan kita sehari-hari, baik dalam keluarga maupun masyarakat. Di zaman modern saat ini, perkembangan ilmu pengetahuan dan teknologi menuntut adanya sumber daya manusia yang berkualitas, yang mampu menghadapi berbagai tantangan dan mampu bersaing. Suatu negara dapat mencapai sebuah kemajuan jika pendidikan dalam negara itu baik kualitasnya. Tinggi atau rendahnya 
kualitas pendidikan dalam suatu negara dipengaruhi oleh banyak faktor misalnya dari kurikulum, peserta didik, pengajar, sarana prasarana, dan juga karena faktor lingkungan.

Salah satu faktor yang mempengaruhi sistem pendidikan nasional adalah kurikulum. Kurikulum sebagai suatu perangkat mata pelajaran maupun program pendidikan yang memuat rancangan berbagai jenis pelajaran di sekolah. Dengan adanya kurikulum maka proses belajar-mengajar di sekolah dapat berjalan dengan baik dan teratur. Kurikulum tentunya wajib di terapkan di setiap sekolah yang ada di Indonesia sesuai dengan ketentuan dan kebijakan yang berlaku. Dengan adanya kurikulum maka aktivitas dalam belajarmengajar yang dilakukan di sekolah mampu memenuhi standar pendidikan. Kurikulum juga harus di gunakan sesuai dengan jenjang pendidikan peseta didik, sedangkan pelaksanaannya adalah proses belajar mengajar, dan yang terlibat di dalam proses tersebut yaitu pendidik dan peserta didik. Oleh karena itu, kurikulum harus dapat mengikuti dinamika yang ada dalam masyarakat. Kurikulum harus bisa menjawab kebutuhan masyarakat luas dalam menghadapi persoalan kehidupan yang dihadapi (Kunandar, 2011: 113).

Pembelajaran saat ini berpedoman pada kurikulum 2013, kurikulum 2013 merupakan hasil pengembangan dari pemerintah melanjutkan kurikulum terdahulu. Aspek yang disempurnakan dalam kurikulum 2013 adalah Standar Kompetensi Lulusan (SKL), Kompetensi Isi (KI), Kompetensi Dasar (KD). SKL yaitu standar kompetensi lulusan merupakan profil lulusan yang diimplikasikan untuk dimiliki oleh setiappeserta didik ketika ia lulus dari suatu jenjang pendidikan baik (SD, SMP, SMA). Dalam SKL terdapat tiga ranah yaitu sikap, pengetahuan dan keterampilan.

Mata pelajaran bahasa Indonesia dalam kurikulum 2013 mengarahkan peserta didik agar mampu mengidentifikasi suatu teks. Teks merupakan ungkapan pikiran yang di dalamnya memiliki suatu situasi dan konteks. Untuk dapat mengidentifikasi informasi dari suatu teks, hal yang harus dilakukan yaitu dengan membaca. Dengan membaca peserta didik mampu mengidentifikasi informasi suatu teks, baik dari segi kata, bahasa maupun struktur kalimatnya, sehingga menghasilkan sebuah pemikiran baru berdasarkan apa yang ada di dalam bacaan tersebut. Menurut Darmawan (2107: 22) mengidentifikasi merupakan kegiatan menentukan dan menetapkan ciri suatu hal yang menjadi tanda kenal tertentu. Hal ini yang menjadi kendala bagi peserta didik. Banyak peserta didik yang beranggapan bahwa kegiatan mengidentifikasi informasi dari suatu teks merupakan kegiatan yang rumit dan membosankan. Padahal kegiatan mengidentifikasi merupakan kegiatan peserta didik dalam menentukan dan menetapkan gagasan atau informasi yang terdapat dalam bacaan tersebut. 
Berkaitan dengan hal tersebut, dalam kurikulum 2013 terdapat materi tentang mengidentifikasi informasi teks eksplanasi. Agar kegiatan pembelajaran menulis teks eksplanasi dapat berjalan dengan baik, guru harus memiliki dasar pengetahuan yang telah tersusun dengan baik dan dasar kemahiran yang telah di miliki dan membimbing peserta didik dengan menggunakan strategi pembelajaran yang tepat. Model pembelajaran yang digunakan guru dalam pembelajaran mengidentifikasi informasi teks eksplanasi harus dapat membuat proses pembelajaran menjadi menarik, menyenangkan, dan melibatkan siswa mejadi lebih aktif. Artinya, dalam hal ini diperlukan model pembelajaran yang dapat meningkatkan pemahaman peserta didik. Model pembelajaram memiliki peran yang sangat penting yang dapat menunjang keberhasilan kegiatan siswa.

Berdasarkan pengalaman selama melakukan Magang 3 dan melakukan observasi di MTsN 2 Medan dengan melakukan wawancara kepada guru bahasa Indonesia Ibu Syarifah Hasibuan, S.Pd. guru bahasa Indonesia di sekolah tersebut. Berdasarkan informasi yang ditemukan kenyataan bahwa siswa kurang mampu mengidentifikasi teks eksplanasi. Permasalahan tersebut muncul karena kurangnya keterampilan membaca, menyimak, menulis dan berbicara siswa. Sehingga, siswa kurang aktif dalam mengikuti proses pembelajaran. Salah satu penyebabnya adalah kurangnya variasi model pembelajaran yang dilakukan guru.

Kurangnya variasi dalam model pembelajaran yang diberikan guru menyebabkan siswa menganggap pembelajaran bahasa Indonesia suatu hal yang membosankan, sehingga minat siswa mengikuti pembelajaran dalam hal ini pembelajaran mengenai mengidentifikasi informasi dalam teks teks eksplanasi masih terbilang rendah. Mengidentifikasi informasi teks eksplanasi adalah penyelidikan untuk mengidentifikasi struktur, unsur dan pola penyajian dalam teks eksplanasi. Mengidentifikasi informasi dari teks eksplanasi perlu dikuasai peserta didik. Karena, siswa dituntut mampu menalar dalam mengamati suatu teks. Namun, pada kenyataannya, tidak adanya variasi penggunaan model pembelajaran sangat mempengaruhi keaktifan siswa di dalam kelas.

Kurangnya penggunaan model pembelajaran di sekolah tersebut disebabkan karena kurangnya tingkat pemahaman guru terhadap variasi model pembelajaran yang maha luas. Guru hanya terfokus pada metode mengajar yang diketahui saja, seperti mengajar dengan metode ceramah. Sehingga, menyebabkan proses pembelajaran terkesan monoton dan menyebabkan peserta didik menjadi pasif dalam mengidentifikasi informasi teks eksplanasi dalam proses pembelajaran. Agar hasil belajar peserta didik meningkat, diharapkan guru dapat menggunakan model pembelajaran yang sesuai. 
Model yang digunakan dalam kegiatan mengidentifikasi informasi teks eksplanasi adalah Model Pembelajaran Aktif Quiz Team. Model quiz team dikembangkan oleh Melvin L Silberman yang berfungsi menghidupkan suasana dalam proses belajar yang mengembangkan kreativitas. Dalam menggunakan Model pembelajaran quiz team ini siswa diharapkan dapat lebih aktif baik bertanya maupun menjawab pertanyaan. Dalam model pembelajaran ini peserta didiki dibentuk dalam kelompok-kelompok kecil yang dimana nantinya dalam anggota itu memiliki tanggung jawab dan saling memotivasi. Rasionalnya, model pembelajaran quiz team ini dapat mempengaruhi kemampuan siswa dalam mengidentifikasi informasi dalam teks eksplanasi, karena model pembelajaran ini adalah model pembelajaran yang berorientasi pada kerja sama siswa dalam suatu tim, dengan menggunakan model ini, siswa lebih bersemangat dan aktif dalam pembelajaran dibandingkan dengan belajar secara mandiri.

Beberapa penelitian menunjukkan bahwa penggunaan model pembelajaran di dalam kelas dapat mempengaruhi hasil belajar peserta didik. Salah satunya penelitian yang dilakukan oleh Octapin A. Tarigan, dkk (2014) dengan judul Penerapan Model Active Learning Type Quiz Team Untuk Meningkatkan Hasil Belajar Siswa Smk Tahun 2016. Dari penelitian tersebut diperoleh hasil bahwa penggunaan model Quiz Team dapat meningkatkan hasil belajar siswa dengan presentase ketuntasan mencapai setelah adanya tindakan sebesar $62,5 \%$ dan termasuk kategori cukup, terdapat 20 orang siswa yang tuntas. Aktifitas belajar siswa pada Siklus II adalah 63,75\%, termasuk dalam kategori tinggi. Prestasi belajar peserta didik pada siklus II sebesar 71,8\%. Termasuk kategori tinggi terdapat 23 orang siswa yang tuntas dan sebagian siswa belum tuntas. Dan penelitian Kusmanto (2015) dalam jurnalnya yang berjudul Penerapan Quiz Team Untuk Meningkatkan Keaktifan dan Prestasi Belajar Matematika Siswa Kelas X-6 SMA Negeri I Imogiri. Dari penelitian tersebut diperoleh hasil bahwa strategi pembelajaran Quiz Team dapat meningkatkan keaktifan dan prestasi belajar matematika siswa kelas X 6 SMA Negeri I Imogiri dengan presentase ketuntasan mencapai $56,4 \%$ pada siklus I dan meningkat menjadi $84,56 \%$ pada siklus II.

\section{Metode}

Metode yang digunakan adalah metode penelitian kuantitatif dengan bentuk eksperimen dan penelitian deskriptif dengan tipe tes awal-tes akhir kelompok tunggal(the one group pre-test-post-test). Metode penelitian eksperimen dapat diartikan sebagai metode penelitian yang digunakan untuk mencari pengaruh perlakuan tertentu terhadapyang lain dalam kondisi yang terkendalikan. 


\section{Hasil dan Pembahasan Penelitian}

\section{A. Hasil Penelitian}

a. Hasil Kemampuan Siswa dalam Mengidentifikasi Informasi dalam Teks Eksplanasi Sebelum Menggunakan Model Pembelajaran Aktif Quiz Team (Pre Test)

Kemampuan mengidentifikasi informasi dalam teks eksplanasi sebelum menggunakan model pembelajaran aktif quiz team, ditunjukkan dalam bentuk tabel di bawah ini.

\section{Tabel 1}

Identifikasi Kecenderungan Hasil Kemampuan Mengidentifikasi Informasi dalam Teks Eksplanasi sebelum menggunakan Model Pembelajaran

Aktif Quiz Team

\begin{tabular}{c|r|r|r}
\hline Rentang & F. & F. & Kategori \\
& Absolute & Relative & Sangat \\
$75-100$ & 1 & $3 \%$ & Baik \\
$60-64$ & 9 & $30 \%$ & Baik \\
$0-59$ & 15 & $50 \%$ & Cukup \\
& 5 & $17 \%$ & Kurang \\
& & & \\
\hline
\end{tabular}

Berdasarkan tabel di atas, dapat diketahui bahwa kemampuan siswa dalam mengidentifikasi struktur dan kebahasaan teks eksplanasi sebelum menggunakan model pembelajaran aktif quiz team terbagi atas, kategori sangat baik 1 siswa (3\%), kategori baik sebanyak 9 siswa (30\%), kategori cukup 15 siswa (50\%), dan kategori kurang 5 siswa (17\%).

b. Hasil Kemampuan Siswa dalam Mengidentifikasi Informasi dalam Teks Eksplanasi Sesudah Menggunakan Model Pembelajaran Aktif Quiz Team (Post Test)

Kemampuan mengidentifikasi informasi dalam teks eksplanasi sesudah menggunakan model pembelajaran aktif quiz team, ditunjukkan dalam bentuk tabel-tabel di bawah ini.

Tabel 2

Identifikasi Kecenderungan Hasil Kemampuan Mengidentifikasi Informasi dalam Teks Eksplanasi Sesudah Menggunakan Model Pembelajaran Aktif Quiz Team 


\begin{tabular}{c|r|r|r}
\hline Rentang & F. & F. & Kategori \\
& Absolute & Relative & Sangat \\
$85-100$ & 19 & $63 \%$ & Baik \\
$70-84$ & 11 & $37 \%$ & Baik \\
$60-69$ & 0 & $0 \%$ & Cukup \\
$0-59$ & 0 & $0 \%$ & Kurang \\
& & & \\
& 30 & $100 \%$ & \\
\hline
\end{tabular}

Berdasarkan tabel di atas, dapat diketahui bahwa kemampuan siswa dalam mengidentifikasi informasi dalam teks eksplanasi sesudah menggunakan model pembelajaran aktif quiz team terbagi atas, kategori sangat baik sebanyak 19 siswa (63\%), kategori baik sebanyak 11 siswa (37\%), kategori cukup 0 siswa (0\%), kategori kurang 0 siswa (0\%).

\section{B. Pembahasan Hasil Penelitian}

a. Kemampuan Mengidentifikasi Informasi dalam Teks Eksplanasi Sebelum Menggunakan Model Pembelajaran Aktif Quiz Team Siswa Kelas VIII MTsN 2 Medan Tahun Pembelajaran 2019/2020

Berdasarkan hasil penelitian, diketahui kemampuan mengidentifikasi informasi dalam teks eksplanasi sebelum menggunakan model pembelajaran aktif quiz team, memperoleh nilai rata-rata sebesar 64,16 dari jumlah siswa sebanyak 30 orang. Kemampuan tersebut belum mencapai KKM yang telah ditentukan MTsN 2 Medan.

Adapun kategori pencapaian kemampuan mengidentifikasi informasi dalam teks eksplanasi tersebut termasuk dalam empat kategori, yaitu dalam kategori sangat baik 1 siswa (3\%), kategori baik sebanyak 9 siswa (30\%), kategori cukup 15 siswa (50\%), kategori kurang 5 siswa (17\%), dan kategori sangat kurang 0 siswa (0\%). Dari nilai rata-rata yang diperoleh siswa tersebut, menunjukkan bahwa kemampuan mengidentifikasi informasi dalam teks eksplanasi sebelum menggunakan model pembelajaran aktif quiz team berada pada kategori cukup.

b. Kemampuan Mengaidentifikasi Informasi dalam Teks Eksplanasi Sesudah Menggunakan Model Pembelajaran Aktif Quiz Team Kelas VIII MTsN 2 Medan Tahun Pembelajaran 2019/2020 
Berdasarkan hasil penelitian, diketahui kemampuan mengidentifikasi informasi dalam teks eksplanasi sesudah menggunakan model pembelajaran aktif quiz team, memperoleh nilai rata-rata sebesar 84,17 dari jumlah siswa sebanyak 30 orang. Kemampuan tersebut sudah mencapai KKM yang telah ditentukan MTsN 2 Medan, yakni sebesar 70.

Adapun kategori pencapaian kemampuan mengidentifikasi mengidentifikasi informasi dalam teks eksplanasi tersebut termasuk dalam empat kategori, yaitu dalam kategori sangat baik sebanyak 19 siswa (63\%), kategori baik sebanyak 11 siswa (37\%), kategori cukup 0 siswa (0\%), kategori kurang 0 siswa (0\%), dan kategori sangat kurang 0 siswa (0\%). Dari nilai rata-rata yang diperoleh siswa tersebut, menunjukkan bahwa kemampuan mengidentifikasi informasi dalam teks eksplanasi sesudah menggunakan model pembelajaran aktif quiz team berada pada kategori sangat baik.

\section{c. Pengaruh Model Pembelajaran Aktif Quiz Team Terhadap Kemampuan Mengidentifikasi Informasi dalam Teks Eksplanasi pada Siswa Kelas VIII MTsN 2 Medan Tahun Pembelajaran 2019/2020}

Berdasarkan uraian di atas, diperoleh hasil penelitian yang menunjukkan nilai ratarata untuk kemampuan mengidentifikasi informasi dalam teks eksplanasi siswa pada tahap sebelum menggunakan model pembelajaran aktif quiz team tergolong pada kategori cukup dengan nilai rata-rata 64,16 sedangkan tahap sesudah menggunakan model pembelajaran aktif quiz team memiliki nilai rata-rata sebesar 84,17 dan termasuk dalam kategori sangat baik. Sehingga dapat disimpulkan bahwa model pembelajaran aktif quiz team berpengaruh dalam meningkatkan kemampuan mengidentifikasi informasi dalam teks eksplanasi.

Hal ini sesuai dengan hasil yang diharapkan, yaitu meningkatkan hasil belajar siswa bahwa kemampuan mengidentifikasi informasi dalam teks eksplanasi sebelum menggunakan model pembelajaran aktif quiz team lebih rendah jika dibandingkan dengan sesudah menggunakan model pembelajaran aktif quiz team.

Berdasarkan hasil penelitian, data sebelum dan sesudah menggunakan model pembelajaran aktif quiz team berdistribusi normal. Hal tersebut dapat dilihat dari uji normalitas data sebelum dan sesudah menggunakan model pembelajaran aktif quiz team. Dari pengujian homogenitas juga terbukti bahwa sampel penelitian ini berasal dari populasi yang homogen.

Peningkatan ini juga dapat dibuktikan dari pengujian hipotesis, $T_{\text {hitung }}>T_{\text {tabel }}$ yaitu 9,62>1,67 yang membuktikan bahwa ada pengaruh yang signifikan penggunaan model 
pembelajaran aktif quiz team terhadap kemampuan mengidentifikasi informasi dalam teks eksplanasi pada siswa kelas VIII MTsN 2 Medan Tahun Pembelajaran 2019/2020.

Dapat disimpulkan bahwa kemampuan siswa dalam mengidentifikasi informasi dalam teks eksplanasi berpengaruh baik dalam pembelajaran bahasa Indonesia khususnya dengan menggunakan model pembelajaran aktif quiz team Hal ini memudahkan mereka dalam mengidentifikasi informasi melalui aktif berdiskusi, menarik dalam proses mencari dan menerima ilmu dari teman sebaya.

\section{Simpulan dan Saran}

\section{A. Simpulan}

Dari hasil penelitian yang telah dilakukan, dapat diambil kesimpulan Kemampuan siswa kelas VIII MTsN 2 Medan tahun pembelajaran 2019/2020 dalam mengidentifikasi informasi dalam teks eksplanasi sebelum menggunakan model pembelajaran aktif quiz team dapat dilihat dari rata-rata pre test siswa yaitu sebesar 64,16 dengan kategori cukup pada rentang nilai tetapi tidak memenuhi KKM yang telah ditentukan sekolah yaitu sebesar 70 . Kemampuan siswa kelas VIII MTsN 2 Medan tahun pembelajaran 2019/2020 dalam mengidentifikasi informasi dalam teks eksplanasi sesudah menggunakan model pembelajaran aktif quiz team dapat dilihat dari rata-rata post test siswa yaitu sebesar 84,17 dengan kategori sangat baik dan sudah memenuhi KKM yang ditentukan sekolah. Dengan adanya perlakuan model pembelajaran aktif quiz team ini siswa lebih dirangsang untuk lebih aktif bekerja sama dengan temannya Penggunaan model pembelajaran aktif quiz team berpengaruh untuk meningkatkan kemampuan mengidentifikasi informasi dalam teks eksplanasi siswa kelas VIII MTsN 2 Medan tahun pembelajaran 2019/2020. Hal ini dapat dilihat dari nilai rata-rata hasil kemampuan mengidentifikasi informasi teks eksplanasi sesudah menggunakan model quiz team lebih tinggi daripada nilai rata-rata hasil kemampuan mengidentifikasi informasi teks eksplanasi sebelum menggunakan model quiz team.

\section{B. Saran}

Berikut ini dikemukakan beberapa saran, yaitu: 1) Seiring dengan perkembangan teknologi, diharapkan guru dapat menciptakan suasana yang berbeda dalam pengajaran, sebagai inovasi dalam mengajar sehingga dapat menarik siswa terutama dalam model pembelajaran agar siswa lebih terlatih untuk berpikir lebih aktif dan meningkatkan kepedulian kepada rekan satu kelompoknya; 2) Pihak siswa diharapkan dapat meningkatkan 
kemampuan mengidentifikasi informasi dalam teks eksplanasi. Untuk guru bidang studi bahasa Indonesia, dapat menjadikan model pembelajaran quiz team sebagai salah satu alternatif untuk meningkatkan hasil kemampuan mengidentifikasi teks eksplanasi. 3) Perlu dilakukan penelitian lanjut oleh peneliti lain dengan mencari model-model pembelajaran lain yang digunakan sekolah khususnya untuk melihat kemampuan mengidentifikasi informasi dalam jenis teks lain.

\section{Daftar Pustaka}

Ekosasih, E. 2019 Jenis Teks dan Strategi Pembelajarannya. Bandung : Yrama Widya.

Hamruni. 2012. Strategi Pembelajaran. Yogyakarta: Insan Madani.

Istarani. 2011. 58 Model Inovatif (Referensi Guru Dalam Menentukan Model Pembelajaran. Medan: Media Persada

Maisaroh, Rostrieningsih. 2010. Peningkatan Hasil Belajar Siswa Dengan Menggunakan Metode Pembelajaran Active Learning Tipe Quis Team Padamata Pelajaran Keterampilan Di Smk N 1 Bogor. Vol. 8 No. 2. 2010 2012. Penilaian Pembelajaran Bahasa Berbasis Kompetensi. Yogyakarta: BPFE

Sudibyo. 2008. Pembelajaran Menulis Puisi dengan Teknik Akrostik (Online). Tersedia: http://gerbangpendidikan.blogspot.com 